\title{
Leaflet Disruption Due To Calcification
}

National Cancer Institute

\section{Source}

National Cancer Institute. Leaflet Disruption Due To Calcification. NCI Thesaurus. Code C50864.

The disturbance of a cusp of a heart valve secondary to the accumulation of calcium on the valve tissue. This most often results in stenosis of the valve. 